\title{
Macroeconomic Dynamics and the Manufacturing Output in Nigeria
}

\author{
Adegbemi Babatunde Onakoya, FCA PhD
}

\author{
Department of Economics \\ Babcock University, Ilishan - Remo, Nigeria
}

Doi: $10.2478 / \mathrm{mjss}-2018-0024$

\begin{abstract}
This paper examined the impact of the changes in the macroeconomic factors on the output of the manufacturing sector in Nigeria from 1981 to 2015. Preliminary evaluation of the data was conducted using both descriptive statistics and stationarity evaluation. The test indicated that not all the variables are normal. The occurrence of order integration at first level difference necessitated the deployment of the Johansen cointegration test. The findings revealed no short run association among manufacturing output and each of GDP, exchange rate, broad money supply and unemployment rate. Negative relationship existed amongst inflation rate, interest rate, exchange rate, broad money supply on one hand, and manufacturing output. The inflation rate and interest rate, were statistically insignificant. However, significant and positive relationship existed between GDP of the previous year and unemployment on the one hand and manufacturing output on the other, at 5 percent level. The results showed that manufacturing was a veritable engine of economic growth. The post estimation tests showed presence of serial correlation but evidence of heteroscedasticity existed which, made the model inefficient, but its estimator is still unbiased. The study recommended the harmonization of both fiscal and monetary policies for the attainment of macroeconomic stability and avoidance of rapid policy summersaults.
\end{abstract}

Keywords: Exchange rate, Gross Domestic Product, Inflation rate, Interest rate, Manufacturing output, Unemployment rate

\section{Introduction}

The manufacturing sector although important, is not the primary driver of the economy of developed nations. The service sector has gained ascendancy (Aviral, 2011; Szirmai and Verspagen, 2011). The Verdoorn's (1949) and Kaldor's (1975) laws however attest to the primal significance of the manufacturing sector to the economy in the developing countries. This position has been confirmed by Onakoya (2014), Szirmai (2009), Amakom (2012), and Arnold, Javorcik \& Mattoo (2011). The basic inference is that increased labour productivity in manufacturing sector leads to rise in the growth of manufacturing output because of the effect of increased economies of larger production and technical progress. This position has also been reinforced by (Thirlwall, 2013) who postulated that the productivity-enhancing innovations technologies deployed in manufacturing sector engender economies of scale in greater proportion than the spill-over effects of in both of the service and agricultural sectors.

In Nigeria, the contributions of the manufacturing sector to GDP has fluctuated widely over the years. From a paltry $4.8 \%$ at independence in 1960 , it grew fifteen years later to $7.4 \%$ in 1975 . By the end of 1980 , its contribution tumbled to $5.4 \%$ only to surge to its peak of $10.7 \%$, five years later in 1985. Since then, the manufacturing portion of GDP had declined: 1992 (7.9\%), 1997 (6.3\%). The lowest ebb ever was $3.4 \%$ recorded in 2001 , beyond which some traction of $4.21 \%$ was gained in 2009 (Central Bank of Nigeria, 2012). This contributions further moved up to $6.67 \%$ and $6.83 \%$ 
respectively in 2012 and 2013 (National Bureau of Statistics, 2014). The recent economic recession also affected the manufacturing sector. Indeed, there was $8.7 \%$ reduction in industrial production in the fourth quarter of 2016 over the same quarter in 2015. The average production growth was 1.35 $\%$ from 2007 until 2016 with a peak of $20.10 \%$ in the first quarter of 2011 and the lowest record of $10.10 \%$ in the quarter 1 of 2016.

Similar fluctuating trends hold for the growth rates of the macroeconomic variables. There is a manifest challenge of the managing the constituents-macroeconomic variables (inflation rate, interest rate, unemployment rate, exchange rate) and the resultant Gross Domestic Product. The rate of interest rate for example, rose from in Q3 \& Q4 from 12\% to $15 \%$ coupled with an epileptic foreign exchange policy. This resulted from the avowed policy of the Nigerian fiscal authority to 'spend our way' out of economic recession by expansionary government expenditure. This further led to uptrended inflationary throughout 2016 as evident increase consumer prices from $12.8 \%$ in March 2016 through $13.7 \%$ in April and $17.6 \%$ in September. Indeed the core inflation rate in Nigeria increased by $17.85 \%$ in January of 2017 over the correspondent period in 2016. As at August 2016, about 4.58 million were unemployed. In ratio terms, the figure rose from $12.1 \%$ in quarter 1 , through $13.3 \%$ in quarter 2 and $14 \%$ in quarter 3 . As at November 2016, the ratio stood at $17.8 \%$ foreign direct investments and portfolio investments dropped by $-23.75 \%$ and $-9.49 \%$ respectively. Industrial output which stood at -10.1 in the first quarter of 2016 rose to $0.1 \%$ in the second quarter only to crash to $3.6 \%$ and $-8.7 \%$ in the third and fourth quarters of 2016 respectively (Nigeria Industrial Production, 2007 to $2017 \mathrm{https}: / /$ tradingeconomics.com/nigeria/industrial-production).

The objective of this study therefore is to understand the extent and direction by which the management of macroeconomic variables drive the Nigerian manufacturing output. The rest of the study is planned as follows: The review of literature is presented in the next section. In the third section, the employed methodology is discussed. Empirical results and the discussion of findings are covered in the fourth section. The recommendations and conclusions are provided in the concluding section, five.

\section{Literature Review}

\subsection{Theoretical Underpinning}

There are few theories directly underlining the macroeconomic variables with respect to the manufacturing sector. The pristine theory in this arena is the Verdoorn's Law (1949) which states that in the long run, productivity develops proportionally to the square root of output. The Kaldor's (1966) law culminating in the Kaldor-Verdoorn's Law refined this. This is consistent with the Arrow (1962) dynamic technical knowledge learning-by-doing) and the endogenous growth theory spearheaded by Romer (1986). The endogenous theory holds that intrinsic factors significantly engender the growth of the economy through the innovation and investment in human capital (Lucas, 1988 and Grossman \& Helpman, 1991). The highlights of the theory include the beneficial impact of positive spill over externalities of a knowledge based, innovative real sector which, engenders economic growth. This is achieved through the persistent development of the economy which also promotes productivity in the manufacturing sector.

The corollary theories on the relationship between GDP and the various macroeconomic variables include the Okun law (Unemployment), Phillips Curve (inflation), Keynesian, monetarist and neo-Keynesian theories (monetary policy). These theories which also shape the real sector can be condensed into two seemingly conflicting locus. Indeed, the summation of these theories is encapsulated both the finance-led growth hypothesis and the demand-following responses. The former states that the development of the financial sector of the economy propels the real sector and accelerates the growth of the economy through two main channels. These are though the facilitation of physical and human capital accumulation on the one hand and raising the rate of technological progress on the other (Mordi, 2010).

The demand-following hypothesis posits that the development of the real sector fast-tracks financial development. This augments the Capital Arbitrage theory propounded by Samuelson (1948) in which the consequential increase in the foreign reserves of the country may lead to 
increased confidence in the economy and encourage additional foreign direct investments since international ventures seek higher profit. For growth to occur, however there is the need for a relatively stable macro-economic environment characterized with low risk and a condition for attracting investment and boosting entrepreneurial activities. There is therefore the need to keep interest rate and inflation at a manageable limit in an environment of stable exchange rate regime.

\subsection{Review of Empirical Literature}

Several empirical works have explored the connection between the output of the manufacturing sector and macroeconomic dynamics. The first Kaldor (1967) law predicated on a two-year study (1953-1954), conducted using the data of 12 OECD countries established a positive nexus between manufacturing output and economic growth. This was confirmed by Elhiraika (2008) who evaluated data from 36 countries over eight-year period (1980-2007). The rapidity of manufacturing sector growth also propels the economy on the path of accelerated positive growth because of increased share of the manufacturing sector (Penélope \& Thirlwall, 2013). However, Obamuyi, Edun and Kayode (2012) could not confirm an interconnection between economic growth and manufacturing output.

Odior (2013) examined the impact of the stochastic characteristics of each of the Nigerian macroeconomic variables on manufacturing sector between 1975 and 2011 . The result finds that both bank credits and foreign direct investment increase the manufacturing productivity level. The impact of broad money supply was less felt. The Korean investigation by Sundararajan (1987) utilised the dynamic framework of among the debt-equity ratio of firms, interest rates, cost of capital, investment and growth between 1963 and 1981. The report shows disparate affiliations with respect to interest rate and manufacturing productivity. The results of the investigation by Imoughele and Ismaila (2014) reveal that whereas the rate of interest and money supply (broad) were statistically insignificant, the rates of inflation and exchange together with the external reserve were significant, and negatively related to the manufacturing sector output in both the current, and the previous year. A uni-directional causality existed between the real rate of exchange and external reserves and the manufacturing output.

A stagflation phenomenon in Nigeria was reported by Njoku, \& Ihugba (2011) Sanusi (2012), Amassoma, and Nnwosa (2013). This is a situation of concurrent high inflation rate, high unemployment and slowed GDP growth rate. This situation deleteriously affects the manufacturing industry through the inability of policy makers to deploy expansionary and / or stabilization macroeconomic policies. Changes in unemployment are more responsive to changes in output in areas with more manufacturing workers (Owyang, Sekhposyan \& Vermann, 2013). This is corroborated by the work of Berument, Dogan and Tansel (2009) who evaluated macroeconomic policy and unemployment by sectoral economic activity with evidence gathered from Turkey.

Anaman and Osei-Amponsah (2009) deployed the cointegration and error correction techniques in finding out the determinants of manufacturing output in Ghana from 1974 to 2006. They report a long-run a nexus between the output of the manufacturing sector and political stability, the level of per capita real GDP, and the export-import ratio.

These have implications for the performance of the manufacturing sector.

\section{Methodology}

The ipso facto empirical research design is employed this research to investigate the connection between the macroeconomic variables (unemployment, rate of exchange, rate of inflation and interest rate) and the sustainability of the manufacturing output in Nigeria.

\subsection{Sources of Data and Model Specification}

This study utilised secondary data spanning thirty-five year period from 1976 to 2015, sourced from Central Bank of Nigeria Statistical Bulletin (2015). This study adapts the work of Fasanya, Onakoya and Agboluaje (2013). The original model made use of the Keynesian IS-LM framework with 
consideration given to the liquidity puzzle, the price puzzle and the exchange rate puzzles. The original model used in the work is given as:

$\Delta R G D P_{t}=\mathrm{a}_{0}+\mathrm{a}_{1} \Delta \mathrm{GDP}_{\mathrm{t}-1}+\mathrm{a}_{2} \Delta \mathrm{M}_{\mathrm{t}-1}+\mathrm{a}_{3} \Delta \mathrm{IR}_{\mathrm{t}-1}+\mathrm{a}_{4} \Delta \mathrm{INF}_{\mathrm{t}-1}+\mathrm{a}_{5} \Delta \mathrm{REER}_{\mathrm{t}-1}+\mathrm{a}_{6} \Delta \mathrm{ER}_{\mathrm{t}-1}+\mathrm{U}_{\mathrm{t}}$

Where $\alpha_{1}, \alpha_{2}, \alpha_{3}, \alpha_{4}, \alpha_{5}, \alpha_{6}$ are parameters for economic growth (GDP), money supply, interest rate, inflation rate, real exchange rate and external reserve.

The Keynesian IS-LM framework is linked with the Augmented Solow growth model and the endogenous growth theory. The augmented Solow growth model considers investment in human capital as a driver for economic growth, which can be achieved through capital accumulation. For capital to be acquired however, the decisions made as regards to interest rate have to be reasonable as it determines the kind of capital that is existent in an economy (whether it is domestic or foreign capital). Reduction in interest rates triggers inflation and affects the level of investment as people have more capital to purchase goods and services as captured in the liquidity and price puzzles of the Keynesian IS-LM framework.

The endogenous growth model also follows a similar manner as the augmented Solow growth model. According to this model, capital accumulation is key for economic growth, but much emphasis is placed on technological progress. The adapted model incorporates unemployment rate, which is important given the labour-intensive nature of the industrial operation in Nigeria, a developing country. The Real Exchange Rate (REER) replaces external reserve as a more appropriate indicator of external trade. In a mathematical format, the long run growth model is framed as log-linear formula in equation 2:

$M A N U_{t}=\beta_{0}+\beta_{1} G D P_{t-1} \alpha_{2} \Delta \mathrm{M}_{\mathrm{t}-1}+\beta_{3} I N F_{t-1}+\beta_{4} I N T_{t-1}+\beta_{5} \Delta \mathrm{REER}_{\mathrm{t}-1}+\beta_{6} U N E M P_{t-1}+U_{t}$

Where $\beta_{0}, \beta_{1}, \beta_{2} \beta_{3}, \beta_{4}, \beta_{5}$ and $\beta_{6}$ are parameters of the model which are Economic Growth (GDP in the previous year), Money Supply (M2), Interest Rate (INT), Real Exchange Rate (REER) and Unemployment Rate (UNEMP) respectively; $U_{t}$ is the disturbance term. There is the likelihood of possible multicollonearity between the manufacturing output contribution to GDP which, is the dependent variable and one the independent variables, GDP. This has been addressed by utilizing the centered values of the variables in line with the approach recommended by Finch, Bolin and Kelly (2014).

\subsection{Method of Data Analysis}

The empirical estimation is in three phases. In the first segment - pre estimation, the descriptive statistics and unit root tests are conducted in order to understand the nature of the series. In the estimation phase, since the stationarity result reveals all the cointegration are of the first order difference $\mathrm{I}(\mathrm{I})$, the Bounds testing approach designed by Johansen (1988) and Johansen and Juselius (1990) is deployed. The existence of a negative and significant error-correction term value is also indicative of the existence of a long run relationship in the model.

Prior to the estimation of the long-run nexus, the lag length to be used in the model is selected using the likelihood ratio (LR). The study complements the LR test with Schwarz Information Criterion (SIC) as well as Akaike Information Criterion (AIC) statistics. These lag selection criteria enables one to select the smallest lag order with less loss reduction in the degrees of freedom (Gutiérrez, Souza. \& Guillén, 2007).

In order to know the existence of possible short-term relationship and the rate of short run adjustment, the Vector Error Correction Model (VECM) technique is deployed. This is because the error correction models directly estimate the speed at which a dependent variable reverts to equilibrium after a shift in other variables.

\section{Findings and Discussions}

\subsection{Preliminary Analyses}

This section covers the descriptive statistics and stationarity tests, which are presented in turns in Table 1 and 2. 


\subsubsection{Descriptive Statistics}

Table 1: Descriptive Statistics of the Variables

\begin{tabular}{|l|c|c|c|c|c|c|c|}
\hline STATISTICS & LNMANU & LNGDP $_{\mathrm{t}-1}$ & LNMS2 & INF & INT & LNEXRATE & UNEMP \\
\hline Mean & 25.56 & 28.49 & 27.04 & 19.72 & 17.81 & 3.23 & 10.43 \\
\hline Median & 25.69 & 28.70 & 26.99 & 12.23 & 17.80 & 3.09 & 7.00 \\
\hline Maximum & 29.83 & 32.17 & 30.55 & 72.84 & 31.65 & 5.26 & 27.40 \\
\hline Minimum & 22.27 & 24.67 & 23.45 & 5.38 & 8.92 & -0.48 & 1.80 \\
\hline Std. Dev. & $2,390,115$ & 2.53 & 2.44 & 17.94 & 5.039 & 1.94 & 7.95 \\
\hline Skewness & 0.25 & -0.12 & -0.02 & 1.63 & 0.18 & -0.71 & 0.76 \\
\hline Kurtosis & 2.04 & 1.69 & 1.63 & 4.37 & 3.43 & 2.15 & 2.27 \\
\hline Jarque-Bera & 1.73 & 2.58 & 2.73 & 18.17 & 0.44 & 4.03 & 4.17 \\
\hline Probability & 0.42 & 0.28 & 0.26 & 0.00 & 0.80 & 0.13 & 0.12 \\
\hline Sum & 894.62 & 997.23 & 946.32 & 690.01 & 623.18 & 112.89 & 365.10 \\
\hline Sum Sq. Dev. & 194.23 & 217.03 & 203.18 & $10,937.60$ & 863.24 & 128.12 & $2,147.26$ \\
\hline Observations & 35 & 35 & 35 & 35 & 35 & 35 & 35 \\
\hline
\end{tabular}

Source: Authors' computation using E-views 8.0 (2017)

The evidence provided in Table 1 show significant variations in the variables given the large differences between the maximum and minimum values of the series. The series were also, positively skewed except exchange rate, money supply, and lagged GDP. The values, exchange rate, lagged GDP, manufacturing output to gross domestic product, unemployment rate and broad money supply $\left(\mathrm{MS}_{2}\right)$ are platykurtic. Others are leptokurtic. The goodness of fit test (Jacque-Bera) indicates that the series are not normal. Nevertheless, and in order to check stability of the series, the unit root test had to be conducted. The result of the exercise is in the next section.

\subsubsection{Unit Root Test Results}

The results of the Stationarity test based on the Augmented Dickey Fuller (ADF) as recommended for the more intricate set of time series data by Elliott, Rothenberg \& Stock (1996) is presented in Table 2.

Table 2: Unit Root Test Results

\begin{tabular}{|l|c|c|c|c|}
\hline Series & $\begin{array}{c}5 \% \\
\text { Critical Value }\end{array}$ & $\begin{array}{c}\text { Augmented Dickey Fuller } \\
\text { (ADF) Test at First difference (Prob.) }\end{array}$ & $\begin{array}{c}\text { Equation } \\
\text { Specification }\end{array}$ & $\begin{array}{c}\text { Order of } \\
\text { integration }\end{array}$ \\
\hline INF & -2.96 & $-5.35(0.00)$ & Intercept & $\mathrm{I}(1)$ \\
\hline IR & -2.96 & $-5.05(0.00)$ & Intercept & $\mathrm{I}(1)$ \\
\hline LNEXRATE & -2.96 & $-4.96(0.00)$ & Intercept & $\mathrm{I}(1)$ \\
\hline LNGDP & -2.96 & $-5.48(0.00)$ & Intercept & $\mathrm{I}(1)$ \\
\hline LNMANU & -2.96 & $-5.45(0.00)$ & Intercept & $\mathrm{I}(1)$ \\
\hline LNMS2 & -2.96 & $-3.27(0.00)$ & Intercept & $\mathrm{I}(1)$ \\
\hline UNEMPLOYR & -2.96 & $-4.28(0.00)$ & Intercept & $\mathrm{I}(1)$ \\
\hline
\end{tabular}

Source: Authors computation using E-Views 8.0 (2017)

Since all the variables in table are all stationary at first, and as earlier discussed, the Johansen cointegration test is applied for determining the long-run relationship amongst the variables. Prior to this estimation, the optimal lag length is calculated because the cointegration technique is lag sensitive. 


\subsection{Estimation Results}

\subsubsection{Optimal Lag Length Selection}

The selected lag length expounds the consequential implication of the previous year's result of previous year on the current year. The result is provided in Table 3.

Table 3: Selection of Optimal Lag Length Criteria (at 5\% level)

\begin{tabular}{|c|c|c|c|c|c|c|}
\hline Lag length & LR & LogL & AIC & HQ & FPE & SC \\
\hline 0 & NA & -250.96 & 16.12 & $16.22^{*}$ & 0.02 & $16.44^{*}$ \\
\hline 1 & $85.23^{*}$ & -194.14 & 15.63 & 16.48 & $0.02^{*}$ & 18.20 \\
\hline 2 & 58.19 & -139.38 & $15.27^{*}$ & 16.87 & 0.02 & 20.08 \\
\hline
\end{tabular}

\footnotetext{
${ }^{*}$ Lag order selected by each criterion

$\mathrm{LR}=$ sequential modified LR test statistic

$\mathrm{AIC}=$ Akaike information criterion

$\mathrm{HQ}=$ Hannan- Quinn information criterion

FPE $=$ Final prediction error

SC $=$ Schwarz information criterion
}

Source: Authors computation using E-views 8.0 (2017)

The different criterion selected disparate optimal levels. The lowest lag length as prescribed by the Schwarz information criteria $(0)$ is selected.

\subsubsection{Cointegration Test Result}

The Eigenvalue and Trace statistic tests are considered under the Johansen cointegration technique which is based on a hypothesized 5 percent level of significance. The result reported in Table 4.

Table 4: Result of Johansen Co-integration test based on Trace Statistic and Max Eigenvalue

\begin{tabular}{|c|c|c|c|c|c|c|c|}
\hline & & \multicolumn{3}{|c|}{ Trace Statistic } & \multicolumn{3}{c|}{ Max. Eigen Value } \\
\hline No. of CE(s) & Eigenvalue & Trace Statistic & 0.05 Critical Value & Prob. $^{* *}$ & Max-Eigen Value & Critical Value $_{\text {Prob. }}{ }^{* *}$ \\
\hline None $^{*}$ & 0.93 & 238.05 & 125.62 & 0.00 & 81.62 & 46.23 & 0.00 \\
\hline At most 1 & 0.88 & 156.43 & 95.75 & 0.00 & 64.60 & 40.08 & 0.00 \\
\hline At most 2 & 0.76 & 91.83 & 69.82 & 0.00 & 44.77 & 33.88 & 0.00 \\
\hline At most 3 & 0.56 & 47.05 & 47.86 & 0.06 & 25.58 & 27.58 & 0.09 \\
\hline At most 4 & 0.29 & 21.47 & 29.80 & 0.33 & 10.44 & 21.13 & 0.70 \\
\hline At most 5 & 0.20 & 11.03 & 15.50 & 0.21 & 6.92 & 14.27 & 0.50 \\
\hline At most 6 & 0.12 & 4.11 & 3.84 & 0.04 & 4.11 & 3.84 & 0.04 \\
\hline
\end{tabular}

Notes:

Trace test indicates 2 cointegrating eqn(s) at the 0.05 level

Max-eigenvalue test indicates no cointegration at the 0.05 level

* denotes rejection of the hypothesis at the 0.05 level

${ }^{* *}$ MacKinnon-Haug-Michelis (1999) p-values

Source: Authors computation using E-views 8.0 (2017) in line with Johansen (1988) and Johansen and Juselius (1990)

The Johansen co-integration test are optimized at most 6 which means the presence of a long-run connection between the lagged GDP, inflation rate, interest rate, exchange rate, GDP, broad money supply $\left(\mathrm{MS}_{2}\right)$ and unemployment rate. The result of the estimated long-run relationship is presented in Table 5 and equation (6). 


\subsubsection{Vector Error Correction Model}

In order to know the existence of possible short-term relationship, the Vector Error Correction Model is estimated. This is done by integrating the multi-variate time series, the dynamics of which assists the maintenance of the equilibrium in the long-run. The result is reported in Table 5.

Table 5: Vector Error Correction Model (VECM) Result.

\begin{tabular}{|c|c|c|c|c|c|c|c|}
\hline Error Correction: & $\mathrm{D}($ LNMANU,2) & $\mathrm{D}(\mathrm{INF}, 2)$ & $\mathrm{D}(\mathrm{IR}, 2)$ & $\mathrm{D}($ LNEXRATE,2) & $\mathrm{D}($ LNGDP,2) & $\mathrm{D}(\mathrm{LNMS2,2})$ & $\mathrm{D}(\mathrm{UNEM}$ MLOYR $)$ \\
\hline CointEq1 & 0.63 & 17.72 & -4.47 & -0.13 & 0.42 & -0.11 & 1.20 \\
\hline & $(0.198)$ & $(8.19)$ & $(2.02)$ & $(0.22)$ & $(0.09)$ & $(0.06)$ & $(1.30)$ \\
\hline T-stat (Cal) & {$[3.53]$} & {$[2.16]$} & {$[2.22]$} & {$[-0.61]$} & {$[4.61]$} & {$[-1.74]$} & {$[0.92]$} \\
\hline
\end{tabular}

Source: Authors computation using E-views 8.0 (2017)

Since the tabulated absolute T-stats value (2.05) is greater than the calculated values of LNEXRATE (0.61), LNMS 2 (1.74) and UNEMPLOYR (0.92), the null hypotheses is accepted as advised by Lutkepohl (2006). This shows the absence of short run association between manufacturing output and each of GDP, exchange rate, broad money supply and unemployment rate. This does not apply to INF (2.16), IR (2.99), $L N G D P_{t-1}$ (4.61) which is greater than the tabulated $T$-stats value. The results after normalization with respect to the independent variable are presented in Table 6.

Table 6: Result of Vector Error Correction Model Regression Test

\begin{tabular}{|l|c|c|c|}
\hline Variable & Co-Efficient (After Normalization) & Standard Error & T-Statistic \\
\hline LNMANU & 1.00 & & \\
\hline LNGDP & 4.85 & 0.34 & 14.47 \\
\hline INF & -0.00 & 0.01 & -0.69 \\
\hline IR & -0.00 & 0.02 & -0.13 \\
\hline LNEXRATE & -0.66 & 0.20 & -3.25 \\
\hline LNMS2 & -3.58 & 0.31 & -11.73 \\
\hline UNEMPLOYR & 0.19 & 0.03 & 7.45 \\
\hline
\end{tabular}

Source: Authors Computation using E-Views 8.0(2017)

The estimated model is shown in equation 4

$L N M A N U=4.85 L N G D P_{t-1}-0.00 I N F-0.00 I R-0.66 L N E X R A T E-3.58 L N M S 2+0.19 U N E M P L O Y R$

R-squared: 0.77 Adjusted R-squared: 0.54

From equation (4) a positive relationship exists between manufacturing GDP of the previous year. This relationship is statistically significant at 5 percent since the absolute calculated t statistic (14.47) is greater than tabulated t-statistics $\left(2.05 \mathrm{at} \mathrm{df}_{28}\right)$. A percentage increase in unemployment rate would result in an upward rise in LNMANU, which is against the apriori expectation and both variables were statistically significant. The findings revealed no short run association among manufacturing output and each of GDP, exchange rate, broad money supply and unemployment rate.

Negative relationship existed amongst inflation rate, interest rate, exchange rate, broad money supply on one hand, and manufacturing output. The inflation rate, interest rate, were statistically insignificant. However, significant and positive relationship exists unemployment and manufacturing output at 5 percent level. The coefficient of determination $R^{2}$ of 0.77 means that approximately $77 \%$ of the variations in manufacturing output is explained by previous year's total output, inflation rate, interest rate, exchange rate, broad money supply and unemployment rate.

\subsection{Post-Estimation Tests}

The results of serial correlation, autocorrelation of the residuals and heteroscedasticity tests are 
presented in the next sub-sections

\subsubsection{Serial Correlation (Breusch-Godfrey Lm) Test}

The result of the serial correlation test between the variables using the Breusch-Godfrey Lm test is in Table 7.

Table 7: Serial Correlation (Breusch-Godfrey LM) Test

\begin{tabular}{|c|c|c|c|}
\hline F-statistic & 0.12 & Prob. F $(2,25)$ & 0.89 \\
\hline Obs $^{*}$ R-squared & 0.32 & Prob. Chi-Square (2) & 0.00 \\
\hline
\end{tabular}

Source: Authors computation using E-views 8.0 (2017)

The presence of serial correlation is confirmed since the chi-square probability value of 0.00 is less than the 5\% significance level (Breusch, 1978; Godfrey, 1978). The presence of autocorrelation in the residuals is tested next.

\subsubsection{Durbin Watson statistics Tests}

This result of auto-correlation between the residuals is provided in Table 8 .

Table 8: Result of Durbin Watson Autocorrelation Test

\begin{tabular}{|c|c|c|c|}
\hline DW Value $(\mathrm{d})$ & D-Upper $\left(d_{U, \alpha}\right)$ & D-Lower $\left(d_{L, \alpha},\right)$ & Decision Criteria \\
\hline 2.14 & 1.97 & 1.03 & No Decision \\
\hline
\end{tabular}

Source: Authors computation using E-views 8.0 (2017)

The essence of the autocorrelation test is to ascertain if the error terms are interrelated over time. This test is beneficial for the immediate past period. Since the Durbin Watson (d) value of greater than both the lower and the upper threshold values $\left(4-d_{U} \leq \mathrm{d} \leq 4-d_{L}\right)$, the presence of autocorrelation result can be taken as being inconclusive

\subsubsection{Heteroscedasticity (Breusch-Pagan) Tests}

This test developed Breusch and Pagan (1979) checks the presence or otherwise of heteroscedasticity of possible errors in regression estimation. Indeed, its absence is one of the basic assumptions of OLS. The result of the heteroscedasticity is presented in Table 9.

Table 9: Result of Breusch-Pagan-Godfrey Heteroscedasticity Test

\begin{tabular}{|l|c|c|c|}
\hline F-statistic & 5.40 & Prob. F (6,27) & 0.00 \\
\hline Obs $^{*}$ R-squared & 18.54 & Prob. Chi-Square (6) & 0.01 \\
\hline Scaled explained SS & 42.93 & Prob. Chi Square (6) & 0.00 \\
\hline
\end{tabular}

Source: Authors computation using E-views 8.0 (2017)

After estimation, result shows that the Probability or $\mathrm{P}$ Value of the Obs* R-squared is 0.00 which is less than $5 \%$ significance level. In effect, the null hypothesis of heteroscedasticity that of the absence of heteroscedasticity, is not accepted. This means that some of the variables are not homoscedastic. Notwithstanding the presence of heteroscedasticity, the OLS estimator although inefficient is still unbiased because according to Johnson (1972), the true variance and covariance are merely underestimated. This is because as proved by Gujarati and Porter (2009), only the 
dynamic conditional variances have been affected and not the unconditional variances. In addition, Fox (1997) as cited by Gujarati \& Porter, (2009) except the problem is severe, there is no need to worry about unequal error variance. The model validity is not compromised. Also, in some studies by Bickel (1978) and Koenker (1981), the inaccuracy of the Breusch-Pagan-Godfrey test have canvassed with respect to data that are not normal (as is in this case).

\subsection{Discussion of Findings}

An individual review of each macroeconomic variables shows disparate results as presented in turns. With respect to Gross Domestic Product (Lagged), this research upholds the KaldorVerdoorn's Law confirming the beneficial impact of positive spill over externalities of a knowledge based, innovative real sector which, engenders economic growth. It is also corroborates the findings of Anaman and Osei-Amponsah (2009) in the quest for the determinants of the output of the manufacturing industry in Ghana from 1974 to 2006. In similar vein, Amakom (2012) which attributes the efficiency of a country's economy to the strength of its manufacturing sector and the micro-level data estimation by Fazio, Maltese and Piacentino (2011) in Italy came to the same conclusions. The extent of growth is however queried by McCombie (1982) who submitted that short run constrictions including as labour and sectoral bottlenecks may hinder such growth.

This study finds that in Nigeria, the high rate of interest although negative, is not statistically significant in influencing the manufacturing sectoral growth. This is consistent with the Rational Expectancy theoretical proposition of McCallum (1980) and Lucas and Sargent (1979) in which the impact of monetary policy are neutralised by economic agents. This happens when forward-looking expectation adjustments are made particularly given the history of policy summersault by the government especially in Nigeria. The fiscal and monetary policy inconsistency in the country over the years have made manufacturers to become largely impervious to such government pronouncements.

The negative and non-significant impact recorded by this study is consistent with the findings on non-linear connection between inflation and economic growth by Li (2014). When rate of inflation is low, the association is insignificant or even positive to explicate the growth of output. At higher levels inflation is expected to generate a negative and significant impact on economic growth. The Monetarists theory of inflation which posits that increased money supply is effective for increasing the level of employment and production only in the short run because it causes a rise in the production level and a reduction in the natural rate of unemployment. This theory does not find confirmation in the findings of this research. Money supply is both negative and significant in the long run. This is due to the fact that Nigeria has experienced stagflation over the years which mutes the influence inflation on the real sector.

On exchange rate, the result of this study is in line with the Keynesian absorption approach which postulates that currency devaluation increases exports and reduces imports. This should ordinarily affect the national income positively. Within the context of the falling exchange rate in Nigeria, this research corroborates the findings of Enu and Havi (2014) in Ghana where 1\% rise in real exchange rate is related to a reduction of $0.32 \%$ in industrial output. Indeed, the inelastic real exchange rate in Ghana is similar to the $(-0.66 \%)$ in Nigeria due in part to the overly dependence of imported raw materials and machinery required to keep the manufacturing sector going in the two developing economy.

Consistent with the Marxian theory, unemployment is inherent within the unstable capitalist system and periodic crises of mass unemployment are to be expected. The deduction from the third law of Kaldor also holds for this study with respect to the positive relationship between employments in manufacturing sector and manufacturing output growth. Indeed, 1 percent increase in employment is in tandem with 0.19 percent manufacturing growth. The question raised by Nickolas (2015) on how automated work upset structural unemployment rates is germane since this may lead to structural unemployment. It appears that the low level of industrialization and technology adoption in Nigeria may have accounted for the non-crowding out of low skilled workers. Akeju and Olanipekun (2014) and this research paper both concluded that the Okun's law which stated a negative relationship existed between unemployment rate and economic growth was 
invalidated in Nigeria.

A composite discussion of the macroeconomic dynamics reveals that with an adjusted Rsquared of 0.54 , the identified variables accounted for fifty-four percent of the variations in the output of manufacturing sector in Nigeria. Managing the 'five sisters' - macroeconomic variables has proved to be fraught with difficulties given the conflicting inter-linkages and spill over effects on the economy. For example, inflation generates adversative effects on the balance of payment and the foreign exchange reserves. Indeed, high levels of domestic inflation may lead to spike in manufacturing production cost and over valuation of the rate of foreign exchange. Exchange rate policy regime fluctuation may have led to loss of confidence and consequential capital flight as experience in the Nigeria in 2016 and the first half of 2017. These led to closure of factories as the dearth of foreign currency hindered the importation of requisite raw materials, machinery and spare parts for the industrial sector.

The conflicting responses of the component macroeconomic variables and the fluctuating performances of the manufacturing sector calls for greater balancing of the fiscal and monetary policies authorities.

\section{Conclusion}

The empirical findings in this study reflected the dynamics of the macroeconomic environment. Whereas the output of the manufacturing sector was positively and significantly related to both GDP and unemployment, it was had a negative but statistical significant relationship with broad money supply and exchange rate. Inflation rate, interest rate were also negative but insignificant. The presence of serial correlation, absence of homoscedasticity, inconclusive result on auto-correlation tests did not invalidate the robustness of the estimation model.

The management of the macroeconomic variables is encapsulated in the fiscal and monetary policies. There is the need for these strands of economic policies to be harmonized if sustainable development is to be achieved. The discordant tunes from the fiscal and monetary authorities to the management of the recent $\left(2016 Q_{1}\right.$ to $\left.2017 Q_{2}\right)$ economic recession experienced in Nigeria further compounded the malaise. The Economic Recovery and Growth Plan (2017-2020) of the Nigerian government aimed at stabilizing the macroeconomic environment may be a panacea to this dichotomous planning malaise.

However, as observed by Ajayi (2011), the low of the manufacturing sectoral output, can be blamed on poor budget implementation. The government will need to match it words with action by harmonizing both the fiscal and monetary policies and avoid rapid policy summersaults in order to achieve sustainable growth and stable macroeconomic stability.

\section{References}

Ajayi, O. D. (2011). The collapse of Nigeria's manufacturing sector. The Voice News Magazine. Retrieved online at www.the voicenewsmagazine.com on 15/06/2012

Amakom, U. (2012). Manufactured exports in Sub-Saharan African economies: Econometric tests for the learning by exporting hypothesis. American International Journal of Contemporary Research, 2(4), 195206.

Amassoma, D. \& Nnwosa, P. I. (2013). The Impact of Unemployment Rate on Productivity Growth in Nigeria: An Error Correction Modeling Approach, Journal of Economics and Sustainable Development, 4 (9), 90-103.

Anaman, K. A. and Osei-Amponsah, C. (2009), Determinants of the Output of the Manufacturing Industry in Ghana from 1974 to 2006, Ghana Policy Journal, 3, The institute of Economic Affairs, Accra, Ghana.

Arnold, J., Javorcik, B. \& Mattoo, A. (2011). Does services liberalization benefit manufacturing firms? Evidence from the Czech Republic. Journal of International Economics, 85(1), 136-46.

Arrow, K. J. (1962). The economic implications of leaning by doing. Review of Economics and Statistics, June issue 29 (3). Doi: 10.2307/2295952.

Aviral, K. T. (2011). Relationship between industry, agriculture, service sectors and GDP: The Indian experience, International Journal of Economics and Business, 1(1), 11-24.

Berument, M., Dogan, N., \& Tansel, A. (2009). Macroeconomic policy and unemployment by economic activity: Evidence from Turkey. Emerging Markets Finance and Trade, 45(3), 21-34. 
Bickel, P.J. (1978). Using residuals robustly I: Test for heteroscedasticity and nonlinearity, Annals of Statistics 6 , 266-291.

Breusch, T. S. (1978). Testing for autocorrelation in dynamic linear models. Australian Economic Papers. 17, 334-355. doi:10.1111/j.1467-8454.1978.tb00635.x.

Breusch, T.S. \& Pagan, A.R. (1979). A simple test for heteroscedasticity and random coefficient variation, Econometrica, 47, 1287- 1294.

Central Bank of Nigeria (2012). Statement of Accounts and Annual Reports. Abuja: Central Bank of Nigeria

Central Bank of Nigeria (2015). Statistical Bulletin. Retrieved from www.cenbank.org/OUT /2015/ PUBLICATIONS/STATISTICS/2015/PartB/PartB.html

Elliott, G.; Rothenberg, T. J.; Stock, J. H. (1996). Efficient Tests for an autoregressive unit root. Econometrica.64 (4), 813-836.

Elhiraika, B. A. (2008). Promoting manufacturing to accelerate economic growth and reduce volatility in Africa. African Economic Conference. Retrieved from http://www.ukessays.com/dissertation/literaturereview/backwardness-of-developing-regions-like-pakistan.php

Enu, P. \& Havi, E. D. (2014). The manufacturing sector of Ghana: Are there any macroeconomic disturbances? Asia Pacific Journal of Multidisciplinary Research, 2(3), 111-122.

Fasanya, I.O., Onakoya, A. B. \& Agboluaje, M.A. (2013). Does monetary policy influence economic growth in Nigeria? Asian Economic and Financial Review, 2013, 3(5), 635-646

Fazio, G., Maltese, E., Piacentino, D. (2011). Estimating Verdoorn law for Italian firms and regions. MPRA Paper No. 35388, Retrieved from http://mpra.ub.uni-muenchen.de /35388/

Finch, W. H., Bolin, J. \& Kelly, K (2014). Multilevel Modeling Using R, Oxford :Chapman \& Hall CRC Press

Godfrey, L. G. (1978). Testing against general autoregressive and moving average error models when the regressors include lagged dependent variables. Econometrica. 46, 1293-1301

Grossman, G., \& Helpman E. (1991). Innovation and Growth in the Global Economy, Cambridge, Massachusetts: MIT Press

Gutiérrez, C.E.C., Souza, R.C. \& Guillén, O.T.C. (2007). Selection of optimal lag length in cointegrated var. models with weak form of common cyclical features. Working Paper Series No. 139

Gujarati, N. D. (2003). Basic Econometrics (4 ${ }^{\text {th }}$ ed.). New Delhi: Tata McGraw-Hill, 748, 807

Imoughele, L. E. (2014). Empirical investigation of the impact of monetary policy on manufacturing sector performance in Nigeria: 1989 to 2012. International Journal of Education and Research, 2(1), $1-20$

Johansen, S. (1988). Statistical analysis of cointegration vectors, Journal of Economic Dynamics and Control, $12,231-254$

Johansen, S. \& Juselius, K. (1990). Maximum likelihood estimation and inference on cointegration - with Applications to the Demand for Money, Oxford Bulletin of Economics and Statistics, 52, 169-210.

Kaldor, N. (1966). Causes of the Slow Rate of Economic Growth of the United Kingdom. An inaugural lecture. Cambridge: Cambridge University Press.

Kaldor, N. (1967). Strategic Factors in Economic Development. New York: Ithaca.

Kaldor, N. (1975). Economic growth and the Verdoorn Law: A Comment on Mr. Rowthorn's Article. Economic Journal, Vol. 85, Nr. 340. December.

Koenker, R., 1981, A note on studentizing a test for heteroscedasticity, Journal of Econometrics, 17, $107-\mathrm{I} 12$.

Li, M. (2014), Inflation and Economic Growth: Threshold Effects and Transmission Mechanisms. Department of Economics, University of Alberta

Loto, M. A. (2012). Global economic downturn and the manufacturing sector performance in the Nigerian economy. Journal of Emerging Trends in Economics and Management Sciences (JETEMS), 3(1), 38-45.

Lucas, Jr., R. E. (1988). On the mechanics of economic growth. Journal of Monetary Economics, 22(1), 3-42.

Lucas, R.E. \& Sargent, T.J. (1979). Rational Expectation and Econometric Practices. London: Allen \& Unwin

Lutkepohl, H. (2006). New Introduction to Multiple Time Series Analysis. Berlin: Springer, 237-352

McCallum, B. (1980). The significance of rational expectation theory. Challenge, 22, 37-43

Mordi, C.N.O. (2010). The link between the financial (banking) sector and the real economy. Central Bank of Nigeria Economic and Financial Review, 48(4), pp. 1-12.

National Bureau of Statistics (2014). Measuring better: Frequently asked questions on the rebasing / rebenchmarking of Nigeria's Gross domestic product (GDP). Retrieved from: http//www.nigerianstat.gov.ng /index.php//

Nickolas, S. (2015). How does automated work affect structural unemployment rates? Retrieved from: http://www.investopedia.com lask/answers/050715/how-does-automated-work-affect-structuralunemployment-rates.asp?lgl=rira-baseline-vertical May 7,

Njoku, C. N. and Ihugba, O. A. (2011). Unemployment and Nigerian economic growth (1985-2009). Mediterranean Journal of Social Sciences, 2 (6), pp 23-32

Obamuyi, T. M., Edun, A.T. and Kayode, O.F. (2012). Bank lending, economic growth and the performance of the manufacturing sector in Nigeria. European Scientific Journal, 8 (3), 19-36 
Odior, E.S. (2013). Macroeconomic Variables and the Productivity of the Manufacturing Sector in Nigeria: A Static Analysis Approach. Journal of Emerging Issues in Economics, Finance and Banking, (1)5, 362-380

Okun, M. (1962). Potential GNP, its measurement and significance, Cowles Foundation, Yale University, http://cowles.econ.yale.edu/P/cp/p01b/p0190.pdf

Onakoya, A.B. (2014). Contributions of manufacturing in the context of inter-sectoral linkages to economic growth in Nigeria. Ago Iwoye Journal of Social and Behavioual Sciences, 3(1) 81-105

Owyang, M. T., Sekhposyan, T. and Vermann, E.K. (2013). Output and unemployment how do they relate today? The Regional Economist, Federal Reserve Bank of St. Louis. Retrieved from: https://www.stlouisfed.org/ /media/Files/PDFs/publications/pub_assets/pdf/re/2013/d/okuns_law.pdf

Penélope, P-L. \& Thirlwall, A.P. (2013). A new interpretation of Kaldor's first growth law for open developing economies. University of Kent KDPE School of Economics Discussion Papers, 1312. Retrieved from https://www.kent.ac.uk/economics/documents/research/papers/2013/1312.pdf

Rasheed, O. A. (2010). Productivity in the Nigerian Manufacturing Sub-Sector. European Journal of Economics, Finance and Administrative Sciences, 6(8): 1450-2275

Samuelson, P. (1948). International trade and the equalisation of factor prices Economic Journal, 58, 165-184.

Sanusi, A. R. (2012). Macroeconomic policy, output and unemployment dynamics in Nigeria: Is there evidence of jobless growth? Paper presented at the 53rd Annual Conference of the Nigerian Economics Society on Youth Employment and Poverty Reduction in Nigeria held at NICON Luxury Hotel, Abuja between 27th and 30th August

Sundararajan, V. (1987). The debt-equity ratio of firms and the effectiveness of interest rate policy. IMF Staff Papers, 34(2), $260-310$.

Szirmai and Verspagen. (2011), Manufacturing and economic growth in developing countries, 1950-2005, UNUMERIT Working Paper 2011-069.

Thirlwall, A. P. (2013). Economic Growth in an Open Developing Economy: The Role of Structure and Demand. Cheltenham: Edward Elgar.

Verdoorn, J. P. (1949). On the factors determining the growth of labor productivity. In L. Pasinetti (ed.), Italian Economic Papers, Vol. II, Oxford: Oxford University Press, 1993 